\title{
Corrigendum: Complement System Inhibition Modulates the Pro-Inflammatory Effects of a Snake Venom Metalloproteinase
}

\author{
Lygia Samartin Gonçalves Luchini, Giselle Pidde, Carla Cristina Squaiella-Baptistão and \\ Denise V. Tambourgi*
}

Immunochemistry Laboratory, Butantan Institute, São Paulo, Brazil

Keywords: Bothrops pirajai, SVMP, complement system, whole blood model, compstatin

\section{A Corrigendum on}

Complement System Inhibition Modulates the Pro-Inflammatory Effects of a Snake Venom Metalloproteinase

by Luchini, L. S. G., Pidde, G., Squaiella-Baptistão, C. C., and Tambourgi, D. V. (2019). Front. Immunol. 10:1137. doi: 10.3389/fimmu.2019.01137

In the original article, there was an error. The molar concentrations of LPS and C-SVMP, used in the assays, were incorrect.

A correction has been made to the Materials and Methods section, subsection Human Whole Blood Model, paragraph two:

"The human whole blood model described by Mollnes et al. (14) was used. Blood samples

OPEN ACCESS

Approved by:

Frontiers Editorial Office,

Frontiers Media SA, Switzerland

${ }^{*}$ Correspondence:

Denise V. Tambourgi

denise.tambourgi@butantan.gov.br

Specialty section:

This article was submitted to Molecular Innate Immunity,

a section of the journal

Frontiers in Immunology

Received: 18 June 2019 Accepted: 19 June 2019 Published: 03 July 2019

Citation:

Luchini LSG, Pidde G,

Squaiella-Baptistão CC and Tambourgi DV (2019) Corrigendum: Complement System Inhibition

Modulates the Pro-Inflammatory

Effects of a Snake Venom

Metalloproteinase.

Front. Immunol. 10:1539.

doi: 10.3389/fimmu.2019.01539 from healthy consenting donors were collected by venepuncture into tubes containing $50 \mu \mathrm{g} / \mathrm{mL}$ of lepirudin (Refludan ${ }^{\circledR}$, Celgene, NJ, USA), the recombinant form of hirudin, a thrombin-inhibitor anticoagulant that does not interfere with the complement cascade. Immediately after collection, $720 \mu \mathrm{L}$ of the blood samples were incubated with $280 \mu \mathrm{L}$ of PBS $\left(8.1 \mathrm{mM} \mathrm{Na}_{2} \mathrm{HPO}_{4}, 1.5 \mathrm{mM}\right.$ $\mathrm{KH}_{2} \mathrm{PO}_{4}, 137 \mathrm{mM} \mathrm{NaCl}, 2.7 \mathrm{mM} \mathrm{KCl}, \mathrm{pH} 7.4$ ), LPS (lipopolysaccharide from Escherichia coli strain O111:B4, Sigma-Aldrich, MI, USA; $5 \mu \mathrm{M}$ final concentration) or C-SVMP (1 $\mu \mathrm{M}$ final concentration) for 30 minutes in a water bath at $37^{\circ} \mathrm{C}$ under agitation. Under these conditions, C-SVMP did not promote blood coagulation (data not shown), allowing for subsequent analyses of plasma and leukocytes, as described below".

A correction has also been made to the Materials and Methods section, subsection Blood Treatment With Compstatin or Control Peptide, paragraph two:

"Herein, $720 \mu \mathrm{L}$ of the blood samples were pre-incubated with $140 \mu \mathrm{L}$ of diluent buffer (PBS), compstatin (Tocris Bioscience, Bristol, UK; $200 \mu \mathrm{M}$ final concentration) or control peptide (Tocris Bioscience; $200 \mu \mathrm{M}$ final concentration) for $30 \mathrm{~min}$ at $37^{\circ} \mathrm{C}$. Then, $140 \mu \mathrm{L}$ of PBS, LPS $(5 \mu \mathrm{M}$ final concentration) or C-SVMP (1 $\mu \mathrm{M}$ final concentration) were added and incubated for $30 \mathrm{~min}$ in a water bath at $37^{\circ} \mathrm{C}$ under agitation. Plasma and leukocytes were processed for analysis, as described below".

The authors apologize for this error and state that this does not change the scientific conclusions of the article in any way. The original article has been updated.

Copyright (c) 2019 Luchini, Pidde, Squaiella-Baptistão and Tambourgi. This is an open-access article distributed under the terms of the Creative Commons Attribution License (CC BY). The use, distribution or reproduction in other forums is permitted, provided the original author(s) and the copyright owner(s) are credited and that the original publication in this journal is cited, in accordance with accepted academic practice. No use, distribution or reproduction is permitted which does not comply with these terms. 